Bálint Sándor

\title{
Morális klímaváltozás- erkölcsi megújulás
}

Sándor Bálint: Moral climate change - moral renewal

Abstract

The human is a moral beings - because it does not behave as a moral being, - will come to naught. According the advocates of ethics, the not insight of this fact should lead to a global ecological disaster ( to a second flood). The possibility of survival is standing or falling with the possibility of moral action: are we aware of the existence of good or bad? Are we able to distinguish the two? Is our freedom, to choose the good knowing both? And at the and, do we recognize our unavoidable responsibility for our actions? This study is about it.

Key words: climate change, morality, ethics, transformation, behavior

\section{ÖSSZEFOGLALÓ}

Az ember erkölcsi lény, de hogy semmi egyéb tudniillik, ha nem erkölcsi lényként viselkedik, semmivé lesz - ennek belátásában rejlik a globális ökológiai katasztrófa (a második vízözön) etikai-hívők számára talán üdvtörténeti jelentősége. A túlélés lehetősége ma az erkölcsi cselekvés lehetőségével áll vagy bukik: hogy meggyőződtünk-e a jó és a rossz létezéséről, képesek vagyunk-e a kettő megkülönböztetésére, szabadságunkban áll-e a különbség ismeretében a jót választani, végül, hogy felismerjük-e átháríthatatlan felelősségünket cselekedeteinkért? Erről szól a tanulmány.

Kulcsszavak: klímaváltozás, erkölcsiség, etikák, átalakulás, viselkedés

\section{KÖZE AZ ETIKÁNAK A KLÍMAVÁLTOZÁSHOZ?}

Az ember erkölcsi lény, de hogy semmi egyéb tudniillik, ha nem erkölcsi lényként viselkedik, semmivé lesz - ennek belátásában rejlik a globális ökológiai katasztrófa (a második vízözön) etikai-hívők számára talán üdvtörténeti jelentősége. A túlélés lehetősége ma az erkölcsi cselekvés lehetőségével áll vagy bukik: hogy meggyőződtünk-e a jó és a rossz létezéséről, képesek vagyunk-e a kettő megkülönböztetésére, szabadságunkban áll-e a különbség ismeretében a jót választani, végül, hogy felismerjük-e átháríthatatlan felelősségünket cselekedeteinkért? $\mathrm{Ha}$ az ember nem lényege szerint erkölcsi lény - ha nem Homo Ethicus Hungaricus, hanem az erkölcs csupán egyike a Homo-Economicus, a Homo-Faber, a Homo Politicus viselkedését szabályozó alrendszereknek, akkor nincs, ami útját állja a romlásának. A környezetvédelem például mindig alulmarad a gazdasági teljesítmény növeléséhez füződő érdekkel szemben, mivel a környezet kiaknázása lényegéből fakad. Tehát az érték - a környezetvédelem - alulmarad a teljesítményt növelő érdekkel szemben.

\section{Milyen a mai világ és erkölcsisége?}

Egy új kor hajnalát, vagy az összeomlás végnapjait éljük? Válaszúthoz közeledünk: az egész világot érintő fordulóponthoz. A túlélésünk vált kétségessé. Rajtunk múlik, hogy összeomlás következik vagy áttörés egy új tipusú világ felé. A szerző a legújabb tudományos eredményeket felhasználva vázol fel egy új világképet. A tudós által is jelzett konferencia, a kvantumjelenségek, a bioszféra evolúciója, a csillagrendszerek, elemzését, összefüggéseit jelezve mutat egy új világképet, amelyet megismerve magabiztosan haladhatunk a jövőbe. Még irányt válthatunk: kellő időben történő átalakulással békés és fenntartható világot teremthetünk. 
De vajon megtehetjük-e? Einstein azt mondta, egy problémát nem lehet ugyanazzal a fajta gondolkodással megoldani, mint ami a problémát okozta. Mégis jelenleg pontosan ezt próbáljuk tenni. Terrorizmus, szegénység, búnözés, kulturális konfliktus, klímaváltozás, környezetpusztítás, rossz közegészség, még az elhízás és más „civilizációs betegségek” ellen is ugyanazokkal az eszközökkel és módszerekkel küzdünk, amik közvetlenül előidézték a problémát: a hadsereghez vagy a rendőrséghez, technikai megoldásokhoz fordulunk. Nem vettük figyelembe a kellő időben történő átalakulásra irányuló akaratot és elképzelést.

Elfecsérelt évtizedekről írja a szociológus, filozófus, értékkutató Hannkiss Elemér: - Sajnos az, hogy a kádárizmus betegségei (késő feudális torzulások, infantilizmus, felelőtlenség, szolidaritáshiány, elvadult individualizmus, korrupció, közöny, kölcsönös bizalomhiány) még ma is kínozzák, bénítják ezt a szerencsétlen társadalmat... Elfecséreltünk két évtizedet.

Egészséges társadalomban az egyének közös erkölcsiséget vallanak: a helyes és a helytelen, a jó és a rossz megítélése hasonló módon zajlik. A közös morál nélkül az emberek nehezebben vagy alig tudják eldönteni, mit tartsanak jónak vagy rossznak, olyan világban, ahol az

Új erkölcsiség. Hogyan jelenhetne meg és terjedhetne el a társadalomban az új, az egyetemes erkölcsiség. Az erkölcsiség alapjait hagyományosan a vallások: a zsidók és a keresztények tízparancsolata, az iszlám és a buddhisták fogalmazták meg. A tudomány dominanciája visszaszorította a vallási előírások hatását, sok ember a tudománytól várta az iránymutatást. A klasszikus tudomány nem tud felmutatni olyan alapelveket, amelyek egy univerzális erkölcsiség alapelvét képezhették volna. A huszadik század tudósainak túlnyomó többsége nem foglalkozott a morál kérdéseivel. Az 1990-es években tudósok és politikusok is kezdték felismerni, hogy szükség van olyan alapelvekre, amelyek meghatározhatják az emberi viselkedés egyetemes normáit. A Nóbelbékedíjasok egy csoportja 2003. novemberében, leszögezte: az erkölcs megjelenése kiemelkedő fontossággal bír. Az új világképnek a tudományos háttérnek kiemelt szerepe, jelentősége van egy új planetáris_etika megteremtésében. Az etikának meg kell tudnia különböztetni az erkölcsös cselekvést, az erkölcstelentől, ami feltételezi a szabadság létét, és a választás lehetőségét. A szabadságunk mértéke pedig függ a fejlettségi szintünktől, az ebben létező tudatosságtól, a felfogás és a válaszadás összepárosításának a képességétől. A cselekvés terjedelmét befolyásolják a személyes preferenciák, a kultúrából származó hajlamok, tudatosan vagy tudat alatt őrzött értékek és hitek. Az embernél a válaszokat, értékeket az erkölcsiség szempontjából is lehet értékelni. Tehát: egy új planetáris etika kialakítása és múködése a személyiség kultúrájától is függ. Fajunk túlélése szempontjából döntő lehet az ember tudatossága a társadalom azon képessége, hogy az ember képes tanulni, viselkedni, hogy nem csak a génektől függ viselkedése.

Az erkölcsös cselekedet kritériumai és szabályai. $\mathrm{Az}$ egyén viselkedése olyan mértékben tekinthető erkölcsösnek, amilyen mértékben hozzájárul az egyén koherenciájához (összetartozás). Ha egy szervezet belülről koherens, a testi funkciók összehangoltak és hatásosak: a szervezet egészséges. Mikor egy szervnek az egész szervezeten belüli koherenciája nem elégséges, akkor a szervezet beteg, a szervezet immunrendszere beteg. egy ember esetében a külső koherencia a családjához, az őt körülvevő közösséghez, a munkahelyhez, a hazájához, a természethez való kapcsolatával függ össze. A koherencia megteremtése az optimális múködés alapja. $A z$ inkoherencia létrehozása szükségtelen agresszió, erőszak, irracionális széttöredezettség és polarizálódás által egyedi emberi sajátosság. („Minden szétesett, széttört" Ady) Az emberek tudatosan is képesek a testük vagy a közösségük és a környezetük koherenciáját pusztítani, megvan a szabadságuk az erkölcstelen viselkedésre, de dönthetnek az erkölcsös magatartás mellett is. A valódi planetáris etika az inkoherenciát előidéző cselekedeteket elutasítja. A minimum szabályok megkívánják, hogy az egyén cselekedete ne 
ütközzék mások életéhez és fejlődéséhez való jogával: úgy élj, hogy mások is élni tudjanak (például a hajléktalanok). A maximum szabályok pedig azt kívánják: tetteiddel segítsd elő az emberiség szempontjából kedvező dinamikus egyensúly kifejlődését a bioszférában. Tehát: nincs ellentmondás a planetáris etika minimum és maximum szabályai, valamint az új világképen alapuló etika között, a kétféle

\section{A MORÁLIS UNIVERZUM, ERKÖLCSI TÖRVÉNY IS VOLT.}

Ez a tanulmány a civilizáció emberének szól, az ember életének elméletét és gyakorlatát igyekszik vázolni, visszaadni, elemezni, az ember helyét, szerepét ebben az univerzumban. Jelezve: a civilizáció nem fényúzés, nem habostorta, nem merül ki a civilizált viselkedésben. Az emberiség története létének minden idejében ki kellett küzdenie szabadságát, biztonságát, méltóságát. Miért tette ezt? - mert ez volt a lehetőség, hogy életben maradjanak fizikailag, lelkileg, erkölcsileg, szellemileg is. Meggyőződés és remény volt, hogy élete "morális univerzum”, erkölcsi törvény is volt, amely kormányozza őket és igazságot tesz világukban. Ámde az ember nemcsak társa, hanem ellensége is lehet az erkölcsnek, egy olyan világban, ahol a rettenet és a szépség, a sötétség és a fény, a halál és a szeretet küzd egymással. Mindenki lehet jó ember, ha szabadnak született, ám ha mégis láncon van (bezárva és nem szabad) mert búnös, a bún pedig beszennyezi és megrontja az embert, jó megelőzni, kimaradni vétekből, a bűnből (Ne ölj, ne lopj!), aki ezt teszi, „elveszíti önmagát"egzisztenciáját, megbénítja az embert. A bűn és a búntudat nemcsak alapfogalommá válhat az egyéni - társadalmi életvilágban, néhány tudományban, hanem például demoralizálhat morálban, lélektanban, vallási - hívői magatartásban (Freud). A búnözés veszélyes, mert akkor megalázzák, megbélyegzik, megnyomorítják az embert, rossz, mert elértékteleníti az ember lényegét, az egyén életvilágát:

Rabszolga vagyok, tudom, s a rabszolgák gyengék.
De az istenek erősek és felettük az abszolútum áll, az erkölcsi rend.

Vagy a még később törvény szelleme.

Ettől a végső törvénytôl függ a világ.

A ráció és az erkölcs, ha a kettő kapcsolata megzavarodik, ha a racionális érdek és az erkölcsi érték kapcsolat, ha az egyik kapcsolata föléje kerül a másiknak és megsemmisíti, kioltja a másikat például az állam totális hatalma az egyén fölött, akkor nagy a baj - például a zsidók, a cigányok elpusztítása rettenetes bűn, megbocsájthatatlan, emberiségellenes tett. Ámde mi köze az etikának, az erkölcsnek a holokauszthoz? Az, hogy ha az ember - népirtó - ha az ember erkölcsi lény - ha nem erkölcsi lényként viselkedik, semmi lesz, emberi lényege megszúnik. Csak az az ember lehet szabad, akinek van bátorsága arra, hogy hiteles válaszok során át alkossa meg a maga világát. Aki nem vállalkozik erre, vagy kudarcot vall, azt leigázzák a mindennapi élet rutinjai. Kövekből, intézményekből és szimbólumokból a szabadság, a méltóság és az értelem világát fölépíteni egy olyan univerzumban, amelyben lehet, hogy nincs szabadság, nincs méltóság és nincs értelem: ez a nagy emberi kaland.

Énünk mindennapi és társadalmi felépítése ${ }^{7}$

Figyelmünket annak elemzésére irányítjuk, hogy hogyan védelmezik, építik és teljesítik ki énjüket az emberek mindennapi és társadalmi életük során és teszik mindezt a fogyasztási civilizáció korában. Hogy miben vannak az észépítés és az észtorzulások tényezői, elemei és feltételei: a mesélés otthon, a családban, az iskolában, templomban, televízióban, szavak, emberi kapcsolatok, életkori stratégiák, társadalmi és politikai környezet, civilizációs hatások, történelmi változások, szépirodalom, múvészetek. Az ezerarcú ént vizsgálják olyan tudományok, mint: a pszichiátria, társadalmi lélektan, a kulturális antropológia, politológia, szociológia, történettudomány és irodalomtudomány. Az ezerarcú én alapja pedig igen sokféle: többszörös én az életrajz alanya, a megismerés és tudás alanya, a politikai alany, az erkölcsi alany, a személyiség én, az 
egyközpontú én egó, az ember öntudat, az alany, mint akarat, az alany, mint szuverenitás. Tanulságos az én diadala sikere, kudarca és bukása, hogy mi az, ami összeköti az egyéneket és, ami szétzilálja?

Az igazi nagy ugrás, civilizációs robbanás csak az elmúlt néhány évtizedben következett be. A „kettős történelemről” beszélhetünk hazánkban is, százezrek - milliók vannak, élnek régi feudális - húbéri társadalmi keretek, szokások, tulajdonságok, életformák, hitvilág elemei, viszonyai között. Az egyéni életvilág, a mindennapi lét szintjén lassabbak a változások, mint a társadalmi közélet, a politika - jog gazdaság - tudomány - társadalmi alrendszerek, felsőbb intézmények - szintjén. A 16-17. században induló modernizációs folyamatok jelentősen átalakították az emberek életét a Jászkunságban is, de az erkölcsi alapelvek jelentős hányadát érintetlenül hagyták, például a tízparancsolatot.

A hagyományos kultúrákban - Jászkunságban is - a megélhetés kényszere és állandó erőfeszítése töltötte ki az életet, szinte semmi másra nem hagyva idót és energiát, döntő mértékben meghatározva az emberi életet, életmódját, magatartását, vágyait, világlátását. $\mathrm{Az}$ ember a megélhetésért folytatott küzdelemre szocializálta tagjait. Ezt szolgálta a kor erkölcse - a Jászkun öntudat, - ezt tanította a család, az egyház a hittan, az iskola. Ma ezzel szemben, nem a puszta megélhetés a lehetőség és a parancs - ámde helyenként még mindig ez az etalon - hanem a valósítsa meg önmagát programja. A hagyományos társadalmakban a hagyomány volt az igazi érték, ma az újdonság az. Sajnos, manapság a moralitás jóval kevesebb szerepet játszik, az önbeteljesedésben gyakran amorális, erkölcstelen, erkölcsileg semleges folyamatok vannak. Nem vagyunk már túl jók az önvizsgálatban sem. Ma sokkal nehezebb erkölcsileg is megvalósítani önmagát az embernek.

A nagy átalakulás: célok, értékek, magatartásformák
Vannak társadalmi kutatók, akik a hagyományos európai civilizációt és a most kialakuló fogyasztói civilizációt közvetlenül szembeállítják a késői 20. századi civilizációval. A közbülső négy évszázadban fokozatosan kialakult énépítés polgári és nem polgári, kispolgári, szegény, nincstelen, és gazdag létforma tartományára szétbontották, szintjei megosztódtak. Létrejöttek értékes gondolatok az etika történetében (Szent Ágoston, Rousseau, Spinóza etikájáról, Francia és Brit Birodalom etikájáról). A reneszánsz kultúra, az iparosítás, az ipari - kereskedelmi - pénztőke elterjedése, a városiasodás fölgyorsulása, a „proletár reneszánsz” létrehozása, a pénzcsináló tőke, bankok és világpiacok szerveződése az énépítés, az önmegvalósítás új szintjeit, „felsőbb” és „alsóbb” rétegeit teremtette meg.

Ez a reneszánsz csak egy elenyésző számú, zárt elit számára reneszánsz. Figyelembe veendők a patológikus társadalmi jelenségek, veszélyek is, mint például a közösségek bomlása, a bűnözés, kábítószer problémák is. Figyelmet érdemel: a társadalom felső rétegében megfogalmazódó új eszmék, erkölcsi és más értékek, tudat és magatartásformák, többnyire nagy, évtizedes évszázados késéssel szivárognak be a társadalom „alsóbb” rétegeibe, a lent lévő egyéni életvilág kultúrájába. A polgári létforma és a nem polgári, kispolgári létforma más, a lét és jólét keretei eltérőek, amelyekben az emberek nem egyenlően rendelkeznek anyagi és szellemi tôkével, boldogságjavakkal, amelyekre szükség van egy ilyen aktív önmegvalósításhoz (következmény az elidegenedés). Az emberek többsége, elsősorban a falusi és kispolgári nép évszázadokon át élt még lényegét tekintve hagyományos kultúrában.

Az önmegvalósítás különböző szintjei.

„Én az egész népemet fogom, nem középiskolás fokon, tanítani" (József Attila)

$\mathrm{Az}$ önmagunkkal való törődésnek, gondoskodásnak, önmegvalósításnak vannak különböző lehetőségei, útjai, módjai, eszközei, amelyek bizonyos mértékben társadalmilag különböznek, rétegződnek. Van az 
önmegvalósításnak egy polgáribb és van egy népiesebb formája - tartalma. Vannak emberek, akik rendelkeznek azzal a neveltetéssel, műveltséggel, képességekkel, környezettel, anyagi eszközökkel, amelyek lehetővé teszik számukra, hogy az önmegvalósításnak egy gazdagabb formájával foglalkozzanak és a világ helyi kihívására aktívan s pozitívan válaszoljanak. Van idejük, indíttatásuk, múveltségük - egyéni életviláguk arra, hogy elgondolkozzanak helyükről, szerepükről otthonukban, akár a globalizációban, a morális és egyéb klímaváltozásban, akár erkölcsi politikai lényként viselkedve is, kiemelkedő, példamutató emberek példáját követve. És vannak emberek, akiknek kevesebb idejük, energiájuk, képességük és hajlandóságuk van arra, hogy komolyan és tudatosan, kitartóan foglalkozzanak önmaguk személyiségének megalkotásával, fejlesztésével. $\quad A z$ önmegvalósítás és a hatékony környezetformálás relatív egysége, egyensúlya egyike a szép - jó - igazságos magatartásnak, értékeknek, ami akár legfőbb személyes célja, eszménye lehet a személyiségnek. Az ilyen magatartás nem olyan, amivel mindenki rendelkezik, vannak emberek, akiknek legfőbb személyes célja, hogy egy csomó pénzt keressen, vagy, hogy hírnévre tegyen szert, feltúnjön, élvet hajhászó magatartást tanúsítson, uralkodjék mások felett. Kétségtelen, hogy az önmegvalósításnak a fogyasztói civilizáció elterjedésével is meg vannak az értékei és veszélyei is. Bevihetik az embert az agresszív egoizmus formáinak zsákutcájába. Az ember, vallási tanítások szerint is élhet, azonosulhat egy közösséggel, családjával, falujával, elfogadhatja a Föld-etika, a Víz-etika, az Öko-etika, a Munka-etika, a Politika-etika értékeit - elveit - normáit, válhat mindezek hívévé. Választhatja ember a fényúzést, mohóságot, uzsorázást, megalázást, érezhetik az emberek azt is, hogy lét -jog- köz biztonság - bizonytalanság, igazságtalanság világában élnek.

\section{AZ ÁLTALÁNOS ETIKÁRÓL. ERKÖLCSRŐL ÁLTALÁBAN. ${ }^{10}$}

Mi az erkölcs, az etika, az erkölcstan és helye szerepe az emberi cselekvés, megismerés, viselkedés rendszerében: a társadalom és, az énépítés, önmegvalósítás sokféle folyamatában, a morális klímaváltozás alakításában, abban, hogy szebben, jobban, igazságosabban élhessünk - ez az értéketika első és általános világproblémája. Ennek tisztázásához, megismeréséhez szükséges meghatározni, hogy mi az, ami még nem erkölcs, de az erkölcs feltétele. Hogy melyek az erkölcs természeti és társadalmi feltételei melyek nélkül nem létezhet erkölcs. Meg kell határozni az erkölcs, az etika, a morál stb. fogalmát, s hogy az erkölcs, az etika, az erkölcstan mihez kötött, milyen társadalmi szférákban érvényesül. Látni kell az ontológiai - lételméleti - alapjainak körvonalait, köztük azt, hogy miben van az ember lényege, hogy a Homo Sapiens erkölcsi lény is, ha nem viselkedik erkölcsi lényként, akkor is lehet fenség (Ady), de akkor erkölcsi nulla, például ha elégeti a zsidókat (holokauszt) de az, aki az erkölcsi nullának szobrot emel az is erkölcsi e tettében nulla, nem lehet se érdem, se erény. Tehát elemezni lehet és kell az erkölcsi - dolgok, viszonyok - tulajdonságok jellemzőit, világban a jó és a rossz világát, mértékét. Tisztázni kell az erkölcs és az emberi megismerés viszonyát, az erkölcsi szocializáció múködését, a múlt értékének átörökítését a családban, iskolában, kortárscsoportokban, a munka és a közélet világában. Hogy az erkölcsi értékek hogyan integrálódhatnak a civilizációban, a társadalom kulturális, politikai, gazdasági, tudomány alrendszereiben, intézményeiben vagy nem, vagy kevésbé, mert kevés bennük az olyan egyén, aki erkölcsi lényként magatart, viselkedik, szabadnak születik, de láncon van.

a) Az erkölcs természeti feltételei (vázlat) $A z$ ösztönök az-az ember-erkölcs legalapvetőbb természeti feltételei. Az állat legalapvetőbb ösztöne az önfenntartási ösztön, melyet az etika történetében többször hamisan 
azonosították az önszeretettel, az élvezetkereséssel, az önzéssel, a haszonnal, ami pedig már gazdasági viszony. Ide tartozik a fajfenntartási ösztön két megnyilvánulási formája a nemi ösztön és az utódok gondozásának ösztöne az anyai ösztön. Igen fontosnak tartják a biológusok és a szociológusok a szociális ösztön kialakulását, az emberek összetartozási érzését, magatartási készségeit, az embernél kialakuló ösztönöket - nem ösztönöket önuralmat, életszükségleteket, mint emberi jelenségeket.

$\mathrm{Az}$ érzetek melyek az erkölcsi megismerésben, cselekvésben nagy szerepet játszanak: az öröm, a szomorúság, a félelem és az igazságérzet (Spinóza, Hobbes). Ám, az amit az állat érez, erkölcsi tartalma nincs, de az állatnál is megtalálhatunk olyan érzelmeket mint a szeretet, gyúlölet, féltékenység, hűség, szimpátia. A többi érzelmek viszont társadalmi jellegúek, lehetnek hasznos vagy káros szükségletet kielégítők stb.

A szenvedélyek emberi jellege. Itt már teljesen emberi birodalomba léptünk. Igaz, a szenvedély is lehet érzelem: szerelem, barátság, dicsvágy, féltékenység, büszkeség stb. A szenvedély mindig valamilyen célra vonatkozott például a gyermek szeretetre, szülök iránt érzett szeretetre, a hazaszeretetre. Hamis illúziókkal együtt járó szenvedélyek nem vezetnek célok eléréséhez, s erkölcsileg károsak, tönkreteszik az embert.

b) Az erkölcs társadalmi feltételei.

Erkölcsről csak emberi társadalomban lehet beszélni. az emberi társadalom kialakulásától kezdve még nem beszélhetünk mai értelemben vett erkölcsről. Vannak az erkölcs kialakulásának olyan feltételei, mint a munka a nyelv, az emberi megismerés bizonyos foka, az érdek, valaminó társadalmi szükséglet kielégítése. Beszélhetünk gazdasági, politikai, erkölcsi érdekről, vélt érdekről, érdekeltségről, erkölcsi szokásokról. Vannak szokások, amelyek mögül az érdek teljesen kiveszett, más jellegú érdekek tolódnak a szokások mögé. Ide tartoznak a divat, az illem, az etikett.

c) Az individuum és az erkölcs

Individuumról, az egyéniségről akkor beszélhetünk, amikor az emberek céljai és kívánságai egyénenként differenciáltakká válnak, az emberek tulajdonságai különböznek, egészen más a motívumuk szerepe az individuumnál, amikor az individuum az igazi társadalmi, erkölcsi lény, amikor az individualitás kapcsolatban van az emberi öntudat megjelenésével. Ez az emberiség fejlődésének soha el nem pusztítható, nagy vívmánya (,vagyok, mint minden ember fenség" Ady)

d) A voltaképpeni erkölcs. A cselekvés erkölcsi tartalma, tényezői

Az erkölcsi viszony, az egyes ember gyakorlati viszonya: osztálya, rétege, társadalma, az emberiség érdekeihez, szokásokhoz, követelmények összességéhez. Az erkölcs: gyűjtőfogalom, az erkölcs fő oldalai a következők: 1 . az erkölcsi tevékenység, az emberek magatartása, sajátos módon motivált tettei, 2. az emberek erkölcsi viszonyai, a magatartásának az erkölcsre jellemző szabályozásmódja, 3. az erkölcsi tevékenység és az erkölcsi viszonyok az erkölcsi tudatban tükröződnek és rögzülnek, az erkölcs a társadalmi tudat egyik fő formája. Az erkölcsöt nem tekinthetjük különálló szférának - mint például a gazdaságot vagy a politikát, hanem jelenségnek, értéknek, tevékenységnek, viszonynak, tudatformának, mely minden szférában, minden emberi viszonyban jelen lehet és eminens, a valóság minden szférájára jellemző, sokféle területen, s módon múködhet az ember, mint erkölcsi lény! Ezek, mint összefoglaló értékek, erkölcsi kódexek funkcionálhatnak, mint etikák, 
kifejeződhetnek mind cselekvésekben, döntésekben, kutatásokban.

$\mathrm{Az}$ erkölcs jellemzője: az egyéni - társas szükségletek, vágyak, törekvések alapvetése a társadalmi követelményeknek, szabályoknak. Ez az alkalmazkodás nem önkéntes és nem megy végbe harc nélkül, az értékválasz alapján jön létre az individuum, az egyén, mint erkölcsi lény. Az erkölcs sajátossága az állhatatosság és „az egyén karakter ereje”. Karaktererő nélkül nincs erkölcsi magatartás. Az egyén karakterereje jellemvonásainak olyan akarati tulajdonságaival függ össze, mint: önuralom, kitartás, bátorság, illetve kishitúség, gyávaság, vakmerőség. A jellemet alkotó tulajdonságok a személyiség értékelése az erkölcsi nevelés tárgyát képezhetik, mint magatartásértékek. A jellemet alkotó tulajdonságok értékképző fogalmak. Az erkölcs fontos jellemzője az a funkció melyben megtörténik az erkölcsi elvek értékek - kategóriák - normák - szabályok lebontása mindennapi és nem mindennapi életvilágban élő és viselkedő emberek cselekedeteire, ez a lebontás az erkölcs alapvető gyakorlati funkciója. (Szabadság egyenlőség - testvériség, a plurális demokrácia, a piacgazdaság, az igazságosság, az emberi méltóság stb. értékek lebontása hívószavakká, elérhető célokká, etikákká, erkölcsi kódexekké). Az elvont normák, konkrét normák értéke mértéke emberi szükségleteket kielégítő ereje nem ugyan az, az embernek meg kell ismernie, találnia, választania mi és hogyan tartozik rá egy-egy konkrét szituációban. Fontos a megismerés, tanulás, az okosság, a műveltség az "alkalmazási képesség” kultúrában, politikában, a munka és magánélet - közélet világában, tudományban, múvészetben, ezen szférák etikájában. Az erkölcs napról napra átformálja életünket és ez konkrét cselekedetekben, normákban kell, hogy testet öltsön. A mindennapi élet a konkrét normák érvényességének területe nem más, mint szokásrendszer az etika síkján. Ám a társadalomnak nincs egységes szokáserkölcse (elidegenedési jelenségek, réteg jelleg, úr szolga viszony, mohóság stb.) Mindennapi élet négy legfontosabb erénye: szótartás, igazmondás, hála és az elemi húség. Ezekre az erényekre az etikusok, az erkölcstan tanítói joggal hívják fel figyelmünket. Az individualitás mindennapi etikája is részben már nem mindennapiból táplálkozik, ami túl van az egyén mindennapi életvilágán, fenn van a társadalom - kulturális, politikai, gazdasági stb. alrendszereiben, abban integrálódhat, mint közjó, közérdek, közérték, közintézmény. Az értékeket, normákat, az erkölcsi fogalmakat az egyed mindig a világból meríti, melybe beleszületik, amelyben él. Egy elidegenedett világ erkölcse tehát mindig elidegenedő, attól függetlenül, hogy az élet mely szférájában teszi ezt, ám a különböző szférák erkölcse egységének megteremtése igen nagy - nehéz és lassú folyamat „ember küzdj és bízva bízzál”. Az erkölcsnek így két oldala van, csak ez a két oldal együtt az erkölcs. Az egyik oldal az erkölcsi szokások és uralkodó normák (értékek) korábbi korok kialakította, a jelenkorban érvényes szövevénye. A másik az egyes ember erkölcsi érzéke, az a belső érzék, mellyel e szokáshoz és normákhoz viszonyul, a moralitás. Erkölcsi érzéke minden individuumnak van. Akinek tettét erkölcsi érzék motiválja, az moralitás alapján cselekszik. Az egyes ember morális fejlettsége annál nagyobb minél inkább a jó determinálja célját. Kant szerint moralitás nélkül nincs erkölcs és erkölcsös tett, hogy minden emberi cselekedetben a jó célkitűzésének is benne kell lennie. Tehát minden ember lehet jó ember. Ám ha az erkölcsi lény: vétkes, bűnös, életellenes, egoista, önző, erkölcsellenes, tisztességtelen, igazságtalan módon viselkedik, mit ér, mint Homo sapiens?

\section{ERKÖLCS, MORÁL, IDENTITÁS}

Az emberi közösségeknek saját identitásuk, csoport-individualitásuk van és ma is ez a leghatékonyabb tényezője az emberi szocialitásnak, az altruizmusnak, olyan viselkedés, amelynek során valaki egy másik személy érdekében cselekszik, hisz az ember, társas lény. Sokféle részmechanizmusa van a csoportidentitás kialakulásának, ezek három kategóriába sorolhatók. Elsőbe azok, 
amelyeknek múködését a „kulturális normák”, viselkedési szabályok fejezik ki. A másodikba a normákat fenntartó biológiai mechanizmusok tartoznak (érzelmek, imutáció). A harmadik csoportba történő azonosulás a morál, a lojalitás tartozik ide, amelyek a genetikai, erkölcsi, pszichológiai altruizmust szabályozzák. Itt lép be a csoportidentitást biztosító mechanizmusba az erkölcsi elvek, erkölcsi értékkategóriák (a morál az erkölcsiség, az erkölcsi magatartás, erkölcstan vagy etika) elfogadása. Itt válaszolható meg az a kérdés, hogy mi köze van az erkölcsnek a csoport és az egyén egymáshoz történő azonosulásához, ami létrehozza a moralitást, benne a morális klímaváltozást. Az erkölcs első fokozata az, amikor a szabályokat a csoport kényszerei miatt tartják meg (például a megélhetési kényszer a XX. századi Jászkunság településeiben, falvaiban). Második fokozatán az erkölcsöt kényszerítő szankciókat a csoporton (falun) kívülre, ősökre, büntető szellemekre, isteni akaratra vezetik vissza. A harmadik szakaszban jelenik meg a belső meggyőződésen alapuló erkölcs, a humán (emberi) „viselkedésikomplex"

\section{Morális klímaváltozás és az etikák}

A Föld-etika meghatározása szerint jó az, ami segít megőrizni az élő közösségek egységét, stabilitását és szépségét; rossz, ha nem így cselekszünk. De miféle föld? Miféle etika: illő tisztázni ezt. A föld szónak három értelme van. A Föld-etika először is a glóbusz megmentésére szólít fel. Ez az egyetlen hely, ahol az élet csodája zajlik. Másodszor a föld egy helyre utal: a falu határát jelenti, a törzs szállásterületét, a nép hazáját, a tájat, ahol otthon vagyunk, a hon védelmét jelenti. Harmadszor a termőföld védelmét jelenti, a megélhetésünk alapját képezi. A Föld-etika így egyszerre lehet globalista - univerzalista, Jászkun érték, személyes és természetközpontú érték. Magyarország meghatározó értéke a föld, a föld-etika, sajnos - káros, hogy a földből származó javak értékek mostanában kevésbé értékesülnek.
A víz-etika a Föld nagy részét borító, az élethez nélkülözhetetlen folyadékkal foglalkozik. Nagyon értékes szerteágazó dolgokkal, természeti - társadalmi viszonyokkal és tulajdonságokkal foglalkozik, az ember és intézményvilága a víz értékeinek megőrzésében, gyarapításában, jó múködtetésében. Magyarország energetikailag teljesen önellátóvá válhat - nyilatkozta Oláh György a Nóbel-díj átvételekor - sőt akár képes lesz energiát is exportálni, ha megfelelően hasznosítja termálvízkincsét. Az Alföld alatti gázmezők és főként meleg vizeink szénhidrogén-tartalma akkora kincset jelentenek, hogy az megváltoztathatja jövőnket, és energiaforrások tekintetében tényleg önellátókká válhatunk. ${ }^{13}$

A víz-etika témája lehet: a tenger vize, mint földrajzi egység; Európa vizei, Magyarország vizei - Duna - Tisza - Dráva - Balaton stb; árvíz, ivóvíz, fürdővíz; helyiségek - települések vízellátásának kezelése - megfelelő bánásmódja (jó - rossz, hasznos - káros); víznek az életmúködés, valamely tevékenységéhez való racionális kreatív felhasználása; vízgazdálkodás, víz hasznosítás etikája és kártételei elleni tevékenység - jó cselekvés, viselkedés ezek tisztelete értékelése megbecsülése; turizmus, gyógymód, orvosi kezelés; a vízhiány (szárazság) vízbőség (áradás) kezelése; vízi - atom erőmű, vízi közlekedés, Szolnok a Tisza fővárosa ennek értékei etikája.

A teológiai etika megújítása mellett érvelő kutatók arra hivatkoznak, hogy amióta ember van, a „legyen” is van, hogy az élő rendszerek axiológiai (értékelő) rendszerek, mert minden élőlény legalapvetőbb képessége, hogy felismerje a fennmaradása és megújulása jó és rossz körülményeit és viselkedését képes szabályozni. Amit erkölcsön értünk az maga is része az élő világ szabályozásának. Így az erkölcsi megítélés alá eső tényezők: az emberi közösségek, az élőlények társulása, maga a föld, a víz, levegő, túz melynek létén - egységén mértékén (értékein) múlik az élet minősége, fennmaradása (a megyei értékvilág és annak értékelése, újratermelése a Jászkunságban mostanában került a „legyen” előterébe). 
Minden társadalmi rend, a múltjából él, múltját nem lehet eltemetni, be kell vallani, értékeit át kell örökíteni, fel lehet dolgozni, kutatni, hogy mi "legyen” értékelő tevékenységnek kell alávetni (múzeum, levéltár, könyvtár, iskolák, település - várostörténelmi - szociológiai múhelyek, döntéshozó - egyes dolgokat megszüntető, újat építő intézményeket létre kell hozni - kutató, dönteni tudó, épító intézmények múködését etikai értékelő (jó, rossz) megitélés alá eső értékek.

Felelősség - etika, a felelősség vállalásához köti az emberi cselekvést, válaszokat arra a kérdésre, hogy felelős-e az ember tetteiért, azért amit tett, $\mathrm{s}$ azért amit nem tett, de tennie kellett volna? Több-e az erkölcsi felelősség, mint ami az emberi világban létező, univerzumhoz, globalizációhoz, hazánkhoz Jászkunsághoz, jövőnkhöz, amit tudunk, s amit nem tudunk ahhoz kötött? A felelősség problémája a következő kérdéseket öleli fel: képes-e az ember teljesíteni a vele szemben támasztott követelményeket; mennyire helyesen fogta fel és értelmezte ezeket a követelményeket; meddig terjednek cselekvési követelményeinek határai; felel-e az ember a kívánt eredmény eléréséért és cselekvéseinek azon következményeiért, amelyeket külső körülmények befolyásolnak, előre láthatja-e ezeket a következményeket.

A felelősség-etikai kategória, amely az egyénnek a társadalomhoz való viszonyát jellemzi. Az erkölcsi felelősség az egyén erkölcsi tevékenységének és kötelességeinek viszonya, az egyén lehetőségeinek szempontjából vizsgálva. Az erkölcsi felelősség mértéke függ a tömegek társadalmi aktivitásától, az emberek tudatosságától, az ember reális erkölcsi szabadságától, a szabadság megvalósulásának egyik eleme, a személyiség többoldalú fejlődésének függvénye, az ember önmegvalósulásának értékmutatója. Az erkölcsi felelősségre vonásban elsődleges mindig a társadalmi érdek marad, de nagy szerepet játszik a bűnös egyén karakterének, jellemének megváltozása is. Az erkölcsi jellem nagyon fontos etikai érték, ami a magatartásban nyilvánul meg, a személyiség erkölcsi értékelése alá eső és az erkölcsi nevelés tárgyául szolgáló erkölcsi tulajdonságainak összessége. Erkölcsi felelősségre vonás az, amikor az, az ember erkölcsi lényére vonatkozik (az ember erkölcsi lény). Felelősek csak azok a szubjektumok lehetnek, akik az erkölcsöket, a törvényeket életben tartják, támogatják és érvényesítik, azok, akik ezt nem teszik, például a politikai rendszert nem ezekre az értékekre építik alapozzák, előbb-utóbb megbuknak, mint például Róma és Cézár. Az embernek viszont van lehetősége arra, hogy mást is tegyen, mint amit tett, tette, viszonya erkölcsiségének mércéje. Ezért van jogunk hasznos és káros, jó és rossz tettről, jó és rossz emberekről is beszélni $\mathrm{s}$ tudni $\mathrm{mi}$ a helyes, igazságos cselekvés.

\section{HATALOM-ETIKÁJA, POLITIKA-ETIKÁJA, KORMÁNYZÁS ETIKÁJA. (Vázlat)}

Nagyon fontos lehet egy világváltás makró és mikro szerkezetének gyökeres átalakítási folyamatában és a tudomány paradigmaváltásának megteremtésében vizsgálni - elemezni a hatalmat, mint erkölcsi problémát, a politika erkölcs világát, a kormányzás etikáját!

\section{A hatalom és az etika világa}

Azok az egyének, akik a politikai hatalom világába kerültek manapság szembesülni kénytelenek azzal a nyugtalanító úrrel, amely a politikai hatalom helyén tátong. ${ }^{15}$ Például, kilátástalan az ökológia helyzete a politikában: a zöld követelések ellentmondásban állnak a hatalom, a tudás és a vagyon újraelőállítását szabályozó rendszer múködésének logikájával, a túlnyomó többség akaratával. A többség ugyanis a fennálló rendszerben az uralom adott rendjét akarja az ökológia világában is (környezetvédelmet) és nem az aranybánya kitermelését, ami cián mérgezését hozta a Tiszába, itt a gazdagodási haszonérdek szembekerült a közjót szolgáló értékkel a Tisza víz értékvilágával, életvilágával. A ma fejedelmei nem érdeklődnek a hatalom természetrajza, erkölcsisége iránt (mint volt 
Machiavelli), nem akarnak tükörbe nézni bárki is tartja azt eléjük, márpedig számos mértékadó szakember megítélése szerint a hazai gazdasági - demokratikus deficitünk egyik alapvető oka az, hogy a politika, a hatalom, a kormányzás nem épült a közjót szolgáló erkölcsre, etikára, mint például Amerikában, ahol az erkölcs megelőzte a politikát, hívó szó lett az igazságosság, a jólét (létbiztonság), a plurális demokrácia, a béke, ott mindez alkotmányban megkövetelt norma lett. Itt a hatalom, a politika, a (jó) kormányzás nem szerepelt, mint erkölcsi - etikai probléma, mint probléma megoldás (politológiája - etikája pszichológiája), sem úgy, mint a hatalom anatómiájának, a hatalom stratégiájának része, taktika és etika itt nem járt egy úton. Ha a győztes itt mindent visz és az ember csak annyit ér, amennyije van, ott a hatalom, a politikai rend nem etikai, ott nagyon nehéz embernek erkölcsi lényként viselkedni, itt-ott erkölcsileg nullává válhat az én, $s$ fel van adva a lecke a politikának. Ugyanakkor sokan vannak, akik többet és mélyebben akarnak látni - tudni (fecseg a felszín s hallgat a mélynél) a politikai hatalom jelenségeiről, a hatalom anatómiájáról, az emberi lét határhelyzetéről, ahol a rend és a káosz, ahol elkezdődik a harc az új modernebb fejlettebb rendért, (ahol a hatalom szüli a rendet). A politika, mint a hatalom és etika közegén túl a közösségi együttélés jó világa is lehet, (nemcsak a mindenki mindenkinek farkasa). Egyedüli lehetősége az embernek, hogy másokkal együtt cselekedjék, ezáltal magában és másokban létrehozza a rendet. A politika pedig azért képes olyan erővel hatni az emberekre, mert rendet és értelmet visz a cselekvésbe. A társadalmat múködtető rendben, aki a tudatot uralja az a rend őre és biztosítéka, az lehet az állam. Az állam pedig nemcsak politikai, hanem érzelmi, lelki, etikai kötelékekkel füzi össze egységbe tagjait.

\section{POLITIKA ÉS AZ ERKÖLCS - AZ ETIKA ÉS POLITIKA}

Politikai tevékenység minden olyan cselekvés, amelyet egy adott integráció (polisz, állam, osztály, réteg) érdekében mi tudattal hajtunk végre. A politikai tevékenység - a szó szűkebb értelmében - mindig a hatalomért folytatott tevékenység. Egy bizonyos erkölcs mindig hozzátartozott minden egyed reprodukciójához. Minden társadalmi osztálynak, rétegnek van erkölcse. (Az urak erkölcse és a szolgák erkölcs, két különböző erkölcstípus, értékmagatartás, értékelmélet). Az első az „urak” fajában vagy „kasztjában” alakul ki, a második pedig az alávetettek, a "szolgák” között. De korántsem minden társadalmi réteg egyenlő intenzitással politizál, a kollektív öntudat szintjén válnak politikailag tevékeny tényezővé, például a gazdasági -szociális konfliktusokban, figyelembe véve azt is, hogy az egyén szocializálódása folyamatában vált-e politikai lénnyé - vagy nem. Vagyis miként „készül el” az egyén politikai tényezővé, milyen külső és belső hatások eredőjeként jut el oda, hogy a politikai cselekvés alanya, politikai intézmények aktora lehessen. $A z$ ember, mint biológiai lény „félkészen” születik, lassú időszak, sokszálú családi, iskolai, munkahelyi stb. folyamat tanulás, nevelés, genetikai örökség szükséges, hogy az egyén alkalmas legyen politikai tevékenységre, vezetői politikai munkára, döntések meghozatalára. A vezető politikai tevékenység sohasem végezhető csak mindennapi tudattal, e tevékenység (döntés) túllépi a mindennapi élet (család) körét és behatol a társadalom valamelyik feljebb lévő alrendszerébe - intézményébe (politika, jog, gazdaság, oktatás, egészségügy, állam stb.) ott derül ki, hogy az milyen hatással van mások mindennapi életére. A modern társadalmakban (Jászkunságban is) az intézmények egész légiója (iskola, munkahely, önkormányzat, könyvtár, levéltár, múzeum, háziorvos, egyház, rendőrség, bíróság stb.) szerepet játszik a mindennapi életvitelben, ha etikailag is jól integrálódik, ha ezek egymáshoz is kötődnek, együttmúködnek, jól szabályozzák az emberek magatartását. Fontos itt a politika, együttmúködése, elosztás, ${ }^{17}$ az osztozkodás, a tulajdon, a csere, a munkamegosztás funkcióival való tevékenység, ezek kormányzása - érdek - érték vezérlése (az állam). A rangsor, 
a státusz, a ritualizált agresszió fontos eleme a csoportok - intézmények politikájának, etikájának, amelyek mindig a javak elosztása, az együttmúködés, szövetségek alakítása (vagy hiánya - harca) a hatalom gyakorlása körül forog. Tény, hogy ezek a társadalmi alrendszerek többnyire nem valódi közösségként működnek, hanem egy- és többtagú csoportok szerveződéseként, s kizárólag saját érdekből vesznek részt a szervezet működésében. Mindenki versenyre száll a hatalomért (választási - győzelmi kampány) őket kell megnyerni fényes ígéretekkel, vonzó szavakkal (igazságosság, jólét, biztonság, mennyország). Tehát: az emberi közösségeknek saját identitásuk (azonosságuk van), ez hozza létre a jó moralitást, ám a nevezett nagy alrendszereknek ilyen nincs, ez megnehezíti az egyén és csoport (intézmény) egymáshoz történő azonosulását. Összefoglalva: az embernél a rangsor egyes helyeiért folyó versenyzés összefonódik a szabálykövetés, az együttmúködés, az osztozkodás, a tulajdon, a csere a munkamegosztás funkcióival, és ez teszi az emberi csoportok életét olyan hallatlanul bonyolulttá. Igen fontos tehát a politika, a morális klíma és a hatalom központja a kormány.

\section{Irodalomjegyzék}

[1.] Lányi András (2013): Tanulmány. Morális Klímaváltozás. Magyar Tudomány 2013/7

[2.] László Ervin (2008): Milyen a mai világ erkölcsisége? Világváltás. 249. oldal A változás harmonikus útja. Nyitott Könyvmúhely, Budapest

[3.] Hankiss Elemér (2014): Elfecsérelt évtizedek. Figyelő 5152 45. oldal

[4.] László Ervin (2008): Az erkölcsös cselekedet kritériumai és szabályai. Világváltás 154. oldal. Nyitott Könyvmúhely Budapest

[5.] Hankiss Elemér (2013): Elfecsérelt évtizedek. Figyelő 2013/51. 45.oldal

[6.] Hankiss Elemér (1977): A morális univerzum. Az emberi kaland. Helikon Kiadó 107. oldal. A ráció és az erkölcs 141. oldal

[7.] Hankiss Elemér (2005): Énünk mindennapi felépítése. Az ezerarcú én. Osiris Kiadó Budapest, 39. oldal; 230. oldal

[8.] Hankiss Elemér (2005): A nagy átalakulás. Az ezerarcú Én. Osiris Kiadó Budapest 361-365, 374-381. oldal

[9.] Hankiss Elemér(2005): Az önkonstrukció különböző szintjei. Az ezerarcú Én. Osiris Kiadó Budapest 499. oldal

[10.] Heller Ágnes Az erkölcsről általában. A szándéktól a következményig. Magvető Kiadó Budapest 1976. I. rész 15-74.oldal

[11.] Heller Ágnes (1970): Az erkölcs. A cselekvés erkölcsi tartalma, tényezői. A mindennapi élet. Akadémiai Kiadó Budapest 106-128. oldal

[12.] Csányi Vilmos (2006): Erkölcs, morál, csoportidentitás. Az emberi viselkedés. Sanoma Kiadó Budapest 116. oldal, 104. oldal. 64., 67. oldal

[13.] Oláh György (2013): Aki hisz „Magyarország feltámadásában” Figyelő 2013/51-52. 11. oldal

[14.] Etikai kislexikon (1967): Jellem. Kossuth Könyvkiadó 142. oldal

[15.] Csepeli György (2013): A hatalom anatómiája. A hatalom és az ember 9-27.oldal. Kossuth Kiadó

[16.] Heller Ágnes (1970): Politika és az erkölcs. A mindennapi élet. Akadémiai Kiadó Budapest 1970. 191. oldal

[17.] Csányi Vilmos (2006): Az emberi viselkedés, Sanoma Könyvkiadó, Budapest, A humán, viselkedési - komplex 64-67. oldal. 